\title{
HASIL PEMERIKSAAN KADAR CD4 DAN TCM GENEXPERT MTB PADA PASIEN KO-INFEKSI TB-HIV DI RSUD BUDHI ASIH JAKARTA
}

\author{
Prima Nanda Fauziah ${ }^{1}$, Mahmudah ${ }^{1}$, Aruna Gamarani ${ }^{1)}$ \\ ${ }^{1}$ Program Studi Analis Kesehatan, Fakultas Kesehatan, Universitas Mohammad Husni Thamrin \\ Correspondence author: Prima Nnada Fauziah, primanandafauziah@gmail.com, Jakarta, Indonesia
}

\begin{abstract}
ABSTRAK
Human Immunodeficiency Virus (HIV) merupakan faktor risiko yang berperan dalam timbulnya infeksi oportunistik karena lemahnya sistem kekebalah tubuh (CD4 menurun) atau kondisi yang melemahkan sistem imun, salah satu Infeksi Oportunistik tersebut adalah Ko-Infeksi TB-HIV.

Penelitian ini disusun berdasarkan studi pustaka dan hasil analisis data sekunder terhadap suspek pasien TB-HIV yang melakukan pemeriksaan kadar CD4 dan TCM Genexpert MTB di RSUD Budhi Asih Jakarta sebanyak 150 data periode Januari - April 2019.

Berdasarkan hasil data didapatkan sebanyak 56 orang $(37,33 \%)$ dengan jumlah pasien paling banyak dengan TB-HIV pada rentang usia 26 - 35 tahun. Kadar CD4 rendah didapatkan sebanyak 129 orang $(86,0 \%)$. Hasil pemeriksaan TCM didapatkan MTB Detected High sebanyak 128 Orang (85,3\%). Hal ini menunjukan bahwa responden selain terinfeksi HIV juga mengalami ko-infeksi TB.

Apabila Pemeriksaan CD4 dan TCM Genexpert MTB dilakukan bersama maka dapat digunakan untuk mendiagnosa ko-infeksi TB-HIV sehingga penatalaksanaan pengobatan dapat dilakukan lebih tepat.
\end{abstract}

Kata Kunci $\quad$ : Ko-infeksi TB-HIV, CD4, TCM

\begin{abstract}
Human Immunodeficiency Virus (HIV) is a risk factor that plays a role in the onset of opportunistic infections due to weak immune system (cd4 decreased) or conditions that weaken the immune system, one of these opportunistic infections is Co-TB-HIV Infection.

This research was compiled based on library studies and the results of secondary data analysis of TBHIV patients who performed cd4 and TCM Genexpert MTB levels at Budhi Asih Hospital Jakarta as many as 150 data from January to April 2019.

Based on the results of the data obtained as many as 56 people (37.33\%) with the highest number of patients with TB-HIV in the age range of 26 - 35 years. The low CD4 rate was obtained by 129 people (86.0\%). TCM examination results obtained MTB Detected High as many as 128 People (85.3\%). This indicates that respondents other than hiv-infected also have TB co-infection.

If CD4 and TCM Genexpert MTB examinations are carried out together then it can be used to diagnose $T B-H I V$ co-infection so that treatment can be done more appropriately.
\end{abstract}

Keywords : Co-infection tb-HIV, CD4, TCM 


\section{PENDAHULUAN}

Human Immunodeficiency Virus (HIV) merupakan virus yang menyerang sel darah putih di dalam tubuh (limfosit) yang mengakibatkan turunnya kekebalan tubuh (CD4 menurun) atau yang melemahkan sistem imun. Sistem imun yang menurun menyebabkan timbulnya infeksi oportunistik, salah satu infeksi oportunistik tersebut adalah ko-infeksi TB-HIV (KPAD Kab. Jember, 2015). Tuberkulosis adalah suatu penyakit menular yang disebabkan oleh kuman Mycobacterium tuberculosis. Pada tahun 2013, angka kejadian dan prevalensi TB di Indonesia sekitar 460.000 dan 680.000 dari 249 juta penduduk. Pada tahun yang sama, jumlah kematian pasien TB (termasuk ko-infeksi TB-HIV) di Indonesia sebanyak 25 orang di setiap 100.000 penduduk. Secara global pada tahun 2016 terdapat 10,4 juta kasus insiden TBC (CI 8,8 juta-12, juta) yang setara dengan 120 kasus per 100.000 penduduk. Lima negara dengan insiden kasus tertinggi yaitu India, Indonesia, China, Philipina, dan Pakistan (WHO, 2014).

Sistem imun yang melemah menyebabkan Mycobacterium tuberculosis lebih mudah menginfeksi dan menimbulkan penyakit TB sehingga seseorang dapat menderita ko-infeksi TB-HIV. Pada tahun 2013, prevalensi ko-infeksi TB di Indonesia sekitar 3,1\% dengan jumlah yang lebih tinggi di beberapa provinsi, seperti Papua (14\%) dan Bali (3,9\%) (WHO, 2014).

Pemeriksaan laboratorium Ko-Infeksi TB-HIV diantaranya meliputi: Pemeriksaan Test Cepat Molekuler (TCM) untuk mendeteksi Mycobacterium tuberculosis dan pemeriksaan kadar CD4 untuk mengukur jumlah limfosit dalam tubuh. RSUD Budhi Asih menjadi salah satu Rumah Sakit dengan pemeriksaan Labroratorium pada pasien Ko-Infeksi TB-HIV.

Berdasarkan latar belakang tersebut, penulis tertarik untuk melakukan penelitian mengenai Hasil Pemeriksaan kadar CD4 dan TCM GeneXpert MTB pada pasien ko-infeksi TB-HIV di RSUD Budhi Asih Jakarta.

\section{METODE PENELITIAN}

Penelitian ini dilakukan di RSUD Budhi Asih Jakarta pada periode Juli- Agustus 2019. Populasi pada penelitian ini adalah pasien HIV yang mengalami ko-infeksi TB yang dirawat di RSUD Budhi Asih Jakarta. Besar sampel yang digunakan dalam penelitian ini merupakan hasil kadar CD4 dan TCM dari total sampling seluruh pasien HIV yang mengalami ko-infeksi TB yang dirawat di RSUD Budhi Asih Jakarta dalam periode Januari-April 2019. Pengumpulan data ini dilakukan dengan menggunakan data sekunder dari pemeriksaan kadar CD4 dan TCM Genexpert MTB pada pasien Ko-Infeksi TB-HIV dengan cara : Membuat surat permohonan izin pengambilan data Hasil Pemeriksaan Hasil Kadar CD4 dan TCM GeneXpert MTB pada pasien Ko-Infeksi TB-HIV ke bagian sekretariat Universitas M.H. Thamrin. Memberi surat permohonan izin pengambilan data Pemeriksaan Hasil Kadar CD4 dan TCM GeneXpert MTB pada pasien Ko-Infeksi TB-HIV ke bagian Diklat RSUD Budhi Asih Jakarta. Menerima surat balasan permohonan izin yang telah disetujui oleh pihak rumah sakit. Mencatat data 
Pemeriksaan Hasil Kadar CD4 dan TCM GeneXpert MTB pada pasien Ko-Infeksi TB-HIV dan mencatat data-data pendukung lainnya seperti: usia,tanggal lahir dan jenis kelamin pasien. Pengolahan data dilakukan dengan cara perhitungan statistik. Data yang diperoleh adalah data sekunder dari pemeriksaan hasil kadar CD4 dan TCM Genexpert MTB pada pasien Ko-Infeksi TB-HIV, kemudian data diolah dengan uji statistik sederhana menggunakan perhitungan presentase. Data yang meliputi demografi, seperti umur, jenis kelamin dan lain-lain akan disajikan dalam bentuk tabel.

\section{HASIL DAN PEMBAHASAN}

\section{Hasil Penelitian}

Pada hasil penelitian yang telah dilakukan terhadap Hasil Pemeriksaan kadar CD4 dan TCM GeneXpert MTB pada pasien ko-infeksi TB-HIV di RSUD Budhi Asih Jakarta pada bulan Januari - April 2019 diperoleh hasil seperti yang tertera pada tabel berikut ini.

Tabel 1.

Data Hasil Pemeriksaan kadar CD4 dan TCM GeneXpert MTB pada pasien suspek ko-infeksi TBHIV di RSUD Budhi Asih Jakarta Bulan Januari - April 2019 Berdasarkan Usia.

\begin{tabular}{ccc}
\hline $\begin{array}{c}\text { Usia } \\
\text { (Tahun) }\end{array}$ & $\begin{array}{c}\text { Jumlah } \\
(\mathbf{n})\end{array}$ & $\begin{array}{c}\text { Presentase } \\
(\boldsymbol{\%})\end{array}$ \\
\hline $0-5$ thn & 12 & $8 \%$ \\
\hline $5-11$ thn & 5 & $3,33 \%$ \\
\hline $12-16$ thn & - & - \\
\hline $17-25$ thn & 15 & $10 \%$ \\
\hline $26-35$ thn & 56 & $37,33 \%$ \\
\hline $36-45$ thn & 35 & $23,33 \%$ \\
\hline $46-55$ thn & 23 & $15,33 \%$ \\
\hline $56-65$ thn & 4 & $2,67 \%$ \\
\hline Jumlah & $\mathbf{1 5 0}$ & $\mathbf{1 0 0 \%}$ \\
\hline
\end{tabular}

Sumber : Data Sekunder, 2019

Berdasarkan tabel 1 dari 150 pasien suspek TB-HIV dengan usia $0-5$ tahun didapatkan sebanyak 12 orang (8\%), pada usia 5 - 11 tahun didapatkan sebanyak 5 orang $(3,33 \%)$, pada usia $17-25$ tahun didapatkan sebanyak 15 orang (10\%), pada usia 26 - 35 tahun didapatkan sebanyak 56 orang $(37,33 \%)$, pada usia 36 - 45 tahun didapatkan sebanyak 35 orang $(23,33 \%)$, pada usia 46 - 55 tahun didapatkan sebanyak 23 orang $(15,33 \%)$, dan pada usia 56 - 45 tahun didapatkan sebanyak 4 orang $(2,67 \%)$. 
Tabel 2.

Data Hasil Pemeriksaan kadar CD4 dan TCM GeneXpert MTB pada suspek pasien ko-infeksi TBHIV di RSUD Budhi Asih Jakarta Bulan Januari - April 2019 Berdasarkan Jenis Kelamin

\begin{tabular}{ccc}
\hline Jenis Kelamin & $\begin{array}{c}\text { Jumlah } \\
(\mathbf{n})\end{array}$ & $\begin{array}{c}\text { Presentase } \\
(\boldsymbol{\%})\end{array}$ \\
\hline Laki - laki & 99 & $66 \%$ \\
\hline Perempuan & 51 & $34 \%$ \\
\hline Jumlah & $\mathbf{1 5 0}$ & $\mathbf{1 0 0 \%}$
\end{tabular}

Sumber : Data Sekunder, 2019

Berdasarkan tabel 2 dari 150 pasien suspek ko-infeksi TB-HIV didapatkan sebanyak 99 pasien (66\%) berdasarkan jenis kelamin laki-laki dan 51 pasien (34\%) berdasarkan jenis kelamin perempuan.

Tabel 3.

Data Hasil Pemeriksaan kadar CD4 pada suspek pasien ko-infeksi TB-HIV di RSUD Budhi Asih Jakarta Bulan Januari - April 2019

\begin{tabular}{ccc}
\hline Hasil & Jumlah (n) & Presentase (\%) \\
\hline Rendah & 129 & $86,0 \%$ \\
\hline Normal & 16 & $10,7 \%$ \\
\hline Tinggi & 5 & $3,3 \%$ \\
\hline Jumlah & $\mathbf{1 5 0}$ & $\mathbf{1 0 0} \%$
\end{tabular}

Sumber : Data Sekunder, 2019

Nilai Normal CD4 500-1600

Berdasarkan tabel 3 dari 150 pasien suspek ko-infeksi TB-HIV didapatkan Kadar CD4 Rendah 129 orang (86,0\%), Kadar CD4 Normal 16 orang (10,7\%), dan Kadar CD4 Tinggi 5 orang $(3,3 \%)$.

Tabel 4.

Data Hasil Pemeriksaan Genexpert MTB pada suspek pasien ko-infeksi TB-HIV di RSUD Budhi Asih Jakarta Bulan Januari - April 2019.

\begin{tabular}{ccc}
\hline Hasil & Jumlah (n) & Presentase (\%) \\
\hline Very Low & 3 & $2,0 \%$ \\
\hline Low & 7 & $4,7 \%$ \\
\hline Medium & 12 & $8,0 \%$ \\
\hline High & 128 & $85,3 \%$ \\
\hline Jumlah & $\mathbf{1 5 0}$ & $\mathbf{1 0 0 \%}$ \\
\hline
\end{tabular}

Sumber : Data Sekunder, 2019 
Berdasarkan tabel 4 dari 150 pasien suspek ko-infeksi TB-HIV didapatkan Genexpert MTB Very Low 3 orang (2,0\%), Genexpert MTB Low 7 orang (4,7\%), Genexpert MTB Medium 12 orang (8,0\%), dan Genexpert MTB High 128 orang (85,3\%).

\section{Pembahasan}

Pada penelitian ini didapatkan 150 data dari pasien yang melakukan pemeriksaan CD4 dan TCM di RSUD Budhi Asih dengan periode bulan Januari - April 2019. Berdasarkan hasil pada tabel 1 dan 2 menunjukkan bahwa penderita Ko-Infeksi TB-HIV ini lebih banyak diderita oleh laki-laki pada usia 26 - 35 tahun.

Pada tabel 1 dari 150 pasien suspek TB-HIV dengan usia 0 - 5 tahun didapatkan sebanyak 12 orang (8\%). Pada usia 5 - 11 tahun didapatkan sebanyak 5 orang (3,33\%) pasien dengan TB-HIV. Pada usia 17 - 25 tahun didapatkan sebanyak 15 orang (10\%). Pada usia 26 - 35 tahun didapatkan sebanyak 56 orang (37,33\%). Pada usia 36 - 45 tahun didapatkan sebanyak 35 orang $(23,33 \%)$. Pada usia $46-55$ tahun didapatkan sebanyak 23 orang (15,33\%), dan pada usia 56 - 45 tahun didapatkan sebanyak 4 orang $(2,67 \%)$. Hasil ini hampir sama dengan penelitian yang telah dilakukan sebelumnya oleh Innes Angita (2011) dimana persentase tertinggi penderita HIV-AIDS adalah pada usia produktif. Tingginya prevalensi HIV-AIDS pada umur produktif ini disebabkan karena orang pada kelompok umur tersebut merupakan kelompok usia produktif dan aktif melakukan berbagai macam aktifitas, dalam aktifitasnya mereka melakukan kontak dengan orang lain tidak terkecuali kontak dengan penderita HIV-AIDS, selain aktifitas fisik yang besar pada kelompok umur ini, produksi hormon seks pada kelompok umur ini sangat besar sehingga aktifitas seksualnya pun meningkat, bila tidak ada pengendalian diri maka akan terjerumus pada seks bebas yang dapat menyebabkan terjadinya penularan HIV-AIDS (Endang, 2002 dalam Gobel, 2008).

Pada tabel 2 didapatkan sebanyak 99 pasien (66\%) berdasarkan jenis kelamin laki-laki dan 51 pasien (34\%) berdasarkan jenis kelamin perempuan. Penelitian ini sejalan dengan penelitian sebelumnya yang dilakukan oleh Gobel (2008) pada "Survei Karakteristik Penderita HIV-AIDS Di Kota Makassar Tahun 2007" bahwa penderita HIV-AIDS tertinggi ditemukan pada penderita dengan jenis kelamin laki-laki di RSUP Dr. Wahidin Sudirohusodo dan RSU Labuang Baji, dengan jumlah kasus masing-masing 172 orang $(79,3 \%) 91$ dan 72 orang $(80,2 \%)$ sedangkan survei oleh KPA Papua mendapatkan bahwa dari total 3185 kasus HIV-AIDS, 53,44\% diantaranya adalah lakilaki, sisanya 46,56\% adalah perempuan. Perilaku dan pergaulan laki-laki cenderung terlihat lebih rentan tertular HIV-AIDS dibanding perempuan. Hal ini disebabkan laki-laki lebih banyak melakukan aktifitas diluar rumah, bertemu dengan banyak orang, serta berinteraksi dengan berbagai lingkungan sehingga tidak menutup kemungkinan berperilaku risiko tinggi terinfeksi HIV terlebih lagi jika tidak memiliki pengetahuan dan keyakinan beragama yang cukup kuat (Amiruddin R, 2007 dalam Gobel, 2008). 
Pada tabel 3 didapatkan Kadar CD4 Low 129 Orang (86,0\%). Kadar CD4 Medium 16 Orang (10,7\%) dan Kadar CD4 High 5 Orang (3,3\%). Hal ini dikarenakan pada penderita HIV jumlah serta fungsi sel CD4 menurun secara progresif, serta gangguan pada fungsi makrofag dan monosit. CD4 dan makrofag merupakan komponen yang memiliki peran utama dalam pertahanan tubuh terhadap mikobakterium (WHO, 2004). Pada tabel 4 didapatkan hasil terbanyak pada Genexpert MTB High sebanyak 128 Orang (85,3\%) dikarenakan MTB mempunyai komponen penting yaitu Lipoarabinomannan (LAM) yang memiliki kemampuan luas menghambat pengaruh imunoregulator. LAM merupakan kompleks heteropolisakarida yang tersusun dari pospatidilinositol, berperan langsung dalam pengendalian pengaruh sistem imun sehingga MTB tetap mampu mempertahankan kelangsungan hidupnya. Dalam upaya mempertahankan kehidupannya tersebut MTB juga menekan proliferasi limfosit T, menghambat aktivitas makrofag, dan menetralisasi pengaruh toksik radikal bebas. Kemudian penyebab lainnya penurunan kadar CD4 yang signifikan menyebabkan MTB mudah berkembang dengan cepat (WHO, 2004).

\section{SIMPULAN}

Dari 150 pasien yang melakukan pemeriksaan CD4 dan TCM di Rumah Sakit Umum Daerah Budhi Asih Jakarta periode Januari - April 2019, didapatkan hasil : Pasien suspek TB-HIV pada usia 26 - 35 tahun didapatkan sebanyak 56 orang $(37,33 \%)$. Pasien suspek TB-HIV berjenis kelamin laki-laki didapatkan sebanyak 99 orang $(66,0 \%)$, sedangkan pada pasien berjenis kelamin perempuan sebanyak 51 orang $(34,0 \%)$. Pasien dengan kadar CD4 Rendah yaitu sebanyak 129 orang $(86,0 \%)$. Pasien dengan hasil TCM Genexpert MTB High yaitu sebanyak 128 orang $(85,3 \%)$.

\section{UCAPAN TERIMA KASIH}

Penulis mengucapkan terima kasih kepada Rumah Sakit Umum Daerah Budhi Asih dan Prodi D III Analis Kesehatan Universitas MH Thamrin berperan serta dalam penelitian ini.

\section{DAFTAR PUSTAKA}

1. Anonim ${ }^{1}$., 2006. Pedoman Surveilanse Infeksi HIV. Depkes R.I. Dirjen P2L\& PLP. Jakarta

2. Anonim $^{2}$, 2012. Statistik Kasus HIV / AIDS di Indonesia . Availableat:http://spiritia.or.id/Stats/Stat.curr.pdfdiakses

3. Anonim ${ }^{3}$., 2012. Pelatihan Pemeriksaan Terkait HIV bagi Petugas Laboratorium. Dirjen P2PL.Kemenkes R.I.

4. Dabla V. Gupta, Anil K. \& Singh, I. 2015. Spectrum of opportunistic infections among HIV seropositive patients in Delhi region-a study by Delhi state AIDS control society. Journal of Medical Disorders [online] Vol. 3:1. 
5. Girsang, M. 2013. Mycobacterium Penyebab Penyakit Tuberculosis Serta Mengenal Sifat-sifat Pertumbuhannya di Laboratorium. 1st ed. [ebook]. p. 3-4. Diakses di http://pppl.depkes.go.id/

6. Gobel, Fatmah Afrianty. 2008. "Survei Karakteristik Penderita HIV/AIDS di Kota Makassar tahun 2007.” Jurnal Madani FKM UMI Vol.I No.2 (Online). http://isjd.pdii.lipi.go.id

7. Kementerian Kesehatan RI. 2012. Petunjuk Teknis Tata Laksana Klinis Ko-Infeksi TB-HIV. 2012. Ed. 1. p.14-16.

8. Lederman, M.M. Rodriguez, B. \& Sieg, S. 2006. Immunopathogenesis of HIV Infection.

9. Liu, Y. Larsen, R. \& Pogliano, K. 2014. Mycobacterium tuberculosis.

10. Komisi Penanggulangan AIDS Kabupaten Jember. 2015. Mengenal \& Menanggulangi HIV \& AIDS Infeksi Menular Seksual dan Narkoba. Jember: Komisi Penanggulangan AIDS Kabupaten Jember

11. U.S. Department of Health \& Human Services (HHS). 2010. Opportunistic Infections

12. U.S. Department of Health \&Human Services (HHS). 2015. Stages of HIV Infection

13. U.S. Department of Health \& Human Services (HHS). 2016. HIV/AIDS.

14. U.S. Department of Health \& Human Services (HHS). 2016. Tuberculosis (TB).

15. Wells, C. et al. 2007. HIV Infection and Multidrug-Resistant Tuberculosis-The Perfect Storm. The Journal of Infectious Diseases, 196(s1), pp. S86-S107

16. WHO Indonesia. 2014. Indonesia TB Situation Update. Diakses di http://www.searo.who.int/indonesia/topics/indonesiatbsituation2014/en/

17. WHO. (2009). TB Impact Measurement. Geneva 